\title{
Numerical Groundwater Flow Modeling of Dijil River Catchment, Debre Markos Area, Ethiopia
}

\author{
Tadesse Ketemaw ${ }^{1}$, Abdulwassie Hussien², Fethangest Woldemariyam Tesema ${ }^{2}$ and \\ Berihu Abadi Berhe ${ }^{2 *}$ \\ ${ }^{1}$ Amhara Design and Supervision Works Enterprise, Amhara Regional State, P.O. Box 1921, Bahir \\ Dar, Ethiopia. \\ ${ }^{2}$ School of Earth Sciences, College of Natural and Computational Science, P.O. Box 231, Mekelle \\ University, Mekelle, Ethiopia (*berihu.abadi@mu.edu.et; berhag2000@gmail.com)
}

\begin{abstract}
Dijil River catchment is a sub-catchment of the Abay drainage basin and covers $138.28 \mathrm{~km}^{2}$. This paper presents numerical groundwater flow modeling at steady-state conditions, in a single-layer aquifer system under different stress or scenarios. A numerical groundwater flow models represent the simplification of complex natural systems, different parameters were assembled into a conceptual model to represent the complex natural system in a simplified form. The conceptual model was input into the numeric model to examine the system response. Based on geologic and hydrogeological information, confined subsurface flow condition was considered and simulated using MODFLOW 2000. The model calibration accounts matching of 24 observation points with the simulated head with a permissible residual head of $\pm 10 \mathrm{~m}$. The sensitivity of the major parameters of the model was identified during the calibration process. According to the simulated water budget in the model, the simulated inflow is found to be $1.2791870 \mathrm{E}+05 \mathrm{~m}^{3} / \mathrm{day}$ which is nearly equal to the simulated outflow of $1.2791755 \mathrm{E}+05 \mathrm{~m}^{3} /$ day with the difference being only $1.1484375 \mathrm{E}+00 \mathrm{~m}^{3} /$ day. Water budget analysis reveals that outflow from river leakage accounts for $92.8 \%$ of the total outflow and $14.1 \%$ of the total inflow comes from the river leakage in the study area. Three scenarios of increased withdrawals and one scenario of altered recharge were used to study the system response. Accordingly, an increase in well withdrawal in scenario-I (existing wells pump simultaneously), scenario-II (existing drilled wells yield withdrawal increased by $30 \%$ ), and scenario-III (additional eight wells having expected yield of $30 \mathrm{l} / \mathrm{s}$ drill and pump) resulted in an average decline of the steady-state water level by $1.06 \mathrm{~m}, 1.68 \mathrm{~m}$, and $4.46 \mathrm{~m}$, respectively. They also caused the steady-state stream leakage to be reduced by about $2.93 \%, 4.58 \%$, and $11.23 \%$, and subsurface outflow by $9.41 \%, 14.67 \%$, and $37.86 \%$, respectively. A decrease in recharge by $25 \%$ and $50 \%$ results in a decrease of the head by $6.1 \mathrm{~m}$ and $13.4 \mathrm{~m}$ respectively, and a stream leakage decrease by $20.3 \%$, and $40.3 \%$ respectively as compared to the simulated steady-state value. Therefore, adequate groundwater level monitoring wells should be placed in the catchment to control the total abstraction rates from the aquifer and fluctuations in groundwater levels.
\end{abstract}

Keywords: MODFLOW, Numerical modeling, Sensitivity analysis, Scenario, Dijil River.

\section{INTRODUCTION}

Understanding of the hydrogeological parameters such as hydraulic conductivity, transmissivity, and storage coefficients are imperative for groundwater modeling. Models can be used to analyze 
hypothetical flow situations and then gain a general understanding of what type of flow system persists (Anderson and Woessner, 1992).

The use of numerical groundwater flow models in the general groundwater resources management and in evaluating the spatial variations of the important aquifer parameters represents one of the most trustworthy methods of regional hydrogeological investigations (Anderson and Woessner, 2002). Geologic information like geologic maps, geological cross-sections, and well logs together with data on hydrogeologic properties are useful to describe hydrostratigraphic units for the development of a conceptual model (Anderson and Woessner, 2002).

Groundwater models have been applied to four general types of problems: groundwater flow, solute transport, heat flow and aquifer deformation (Wang and Anderson, 1982; Trescott et al., 1976; McDonald and Harbaugh, 1988; Pinder and Gray, 1977; Konikow and Bredehoefet, 1978; Prickett and Lonquist, 1971). Over the last decade, the concern of modeling groundwater flow and transport systems has grown promptly (Zhou and Li, 2011; Huizar-Alvarez et al., 2016; Havril et al., 2017; Mussa et al., 2020). The application of numerical simulations in 2- and 3dimensional models to distinguish the various types of groundwater flow systems is becoming increasingly important for assessing potential groundwater management strategies and simulating under the steady condition and any changes in groundwater budget components in transient conditions in complex basins (Cardenas and Jiang, 2010; Bresciani et al., 2016; Mussa et al., 2020).

Groundwater modeling is being used more frequently as a tool to help answer optimum water management questions because it can lead to a better understanding of how the real system behaves and it can be used to make predictions about the system's future behavior. Today, groundwater flow modeling is the most widely used to solve complicated hydrogeological issues. The foremost importance of numerical modeling is its speed, accuracy of results and reliability of executed calculations (Batu, 2006; Kresic, 2007; Anderson et al., 2015). Groundwater evaluation and management in many countries can be easily handled using an interface called MODFLOW (Wang et al., 2008; Veiko et al., 2013). The easiness, simple structure and ability to handle with separate package for resolving several special hydrogeologic problems can be the comparative advantages of MODFLOW to be applied as a calculation program (Tenbus and Fleck, 1996).

The interaction between groundwater-surface water in the study area has been done by many researchers. Surface water from the Tana Lake percolates through its floor to aquifers of Tertiary volcanic and Mesozoic sedimentary rocks (WWDSE, 2007) and based on baseflow separation and 
numerical modeling techniques, groundwater contribution is less than $7 \%$ of the total inflow to the Lake Tana (Seifu, 2004; Getachew, 2008; Samson, 2010) and groundwater inflow to the lake is insignificant (SMEC, 2007). Abay and Tana basin have various groundwater types that were recorded as a result of hydrogeochemical and isotope studies (Seifu et al., 2005 and 2012).

Even though a number of studies have been undergone in the study area on local and regional levels, the groundwater flow system of the study area is not adequately characterized. Moreover the yield and static water level of the study area are decreasing from time to time. According to Debre Markos town water and sewerage office (2016 and 2017), the yield of and the water level decreases by 131/s and 31 meters on average, respectively. Therefore, this study aims to carry out numerical groundwater flow modeling at steady-state condition, in a single layer (1-D) aquifer system under different stress or scenarios.

\section{STUDY AREA}

The study area, Dijil River catchment, is located in the northwestern part of Ethiopia within the Blue Nile/Abay basin (Fig 1). Geographically, it lays between $347122 \mathrm{mE}$ to $362601 \mathrm{mE}$ and $1139983 \mathrm{mN}$ to $1161150 \mathrm{mN}$, having an area of $138.28 \mathrm{~km}^{2}$ and a perimeter of $82 \mathrm{~km}$.

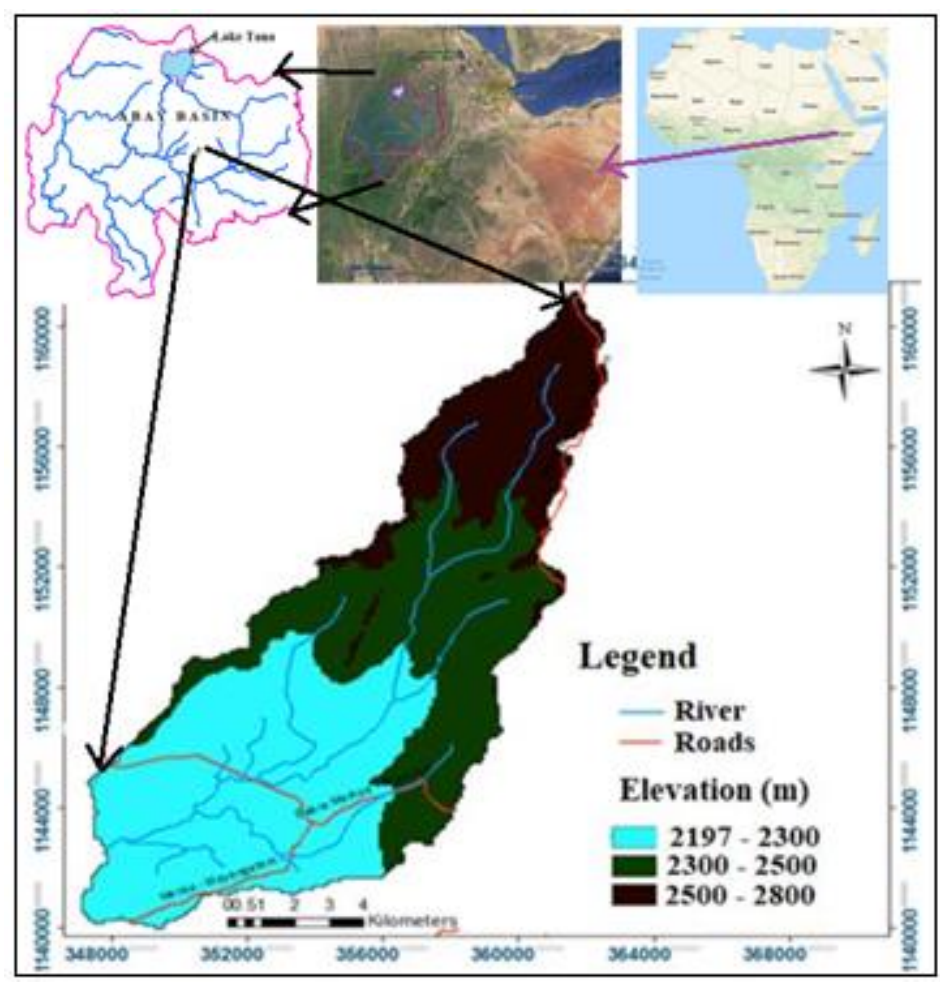

Figure 1. Location map of the study area. 
The study area is characterized by a cool climate with a mean annual temperature range of $10^{\circ} \mathrm{C}$ to $15^{\circ} \mathrm{C}$ and situated in the altitudinal range of 2300 masl to 3300 masl. The climate of the area can be categorized into two broad seasons: the dry season which covers the period from October to May and the wet season extending from June to September, with slight rainfall during autumn and spring (Tenalem and Tamru, 2001). The mean annual precipitation of the area calculated using Thiessen polygon is $1354.15 \mathrm{~mm}$.

\section{GEOLOGY AND HYDROGEOLOGY}

The study area consists of six geologic formations: the Middle (Yujbe) basalts, the Ignimbrite and tuff deposits, the Debremarkos basalts, the Lumame basalts, the Robgebeya basalts and the quaternary eluvial deposits (Fig 2). These geologic formations are described from the oldest to the youngest. The Middle (Yejube) Basalt is dominantly composed of Olivine-plagioclase phyric basalt, plagioclase phyric basalt and at places, it also consists of pockets of pyroxene-plagioclaseolivine phyric basalt and interlayered with pyroclastic (Wolela, 2002; Getaneh, 1991; Ayalew et al., 2015). The Ignimbrite and Tuff are also found intercalated with the basaltic rock of the area. It is composed of tuff, agglomerate, and ignimbrite. The color of tuff shows great variation from light to pinkish-gray and it is fine-grained. The Debremarkos Basalt (Wolela, 2002; Getaneh, 1991; Ayalew et al., 2015) is aphanitic to porphyritic and at places it is vesicular olivine-plagioclase phyric basalt, plagioclase-olivine phyric basalt and olivine phyric basalt, and pyroxene phyric basalt, grading to each other; with minor trachytes and pyroclastic tuff interlayered with the basalt at the top and bottom of the formation. Its topmost part is the hill forming pyroclastic tuff. The Lumame Basalt is characterized by variable phenocryst proportion, olivine-plagioclase phyric basalt, plagioclase phyric basalt, pyroxene plagioclase phyric basalt, pyroxene-olivine phyric basalt and pyroxene phyric basalt (Wolela, 2002; Getaneh, 1991; Ayalew et al., 2015). The top part is overlain by the Choke shield volcano. The Robgebeya basalts are composed of varying phenocryst proportion; plagioclase phyric basalt, olivine phyric basalt, olivine-plagioclase phyric basalt, olivine-pyroxene-plagioclase phyric basalt and pyroxene-olivine phyric basalts. The Quaternary Eluvial sediments are reddish-brown to black clay soils and commonly cover the lowland plain part of the study area (Wolela, 2002; Getaneh, 1991; Ayalew et al., 2015). The sediments are derived from chemical weathering of underlying volcanic rocks or parent rock materials in the upstream of the catchment. 
Most of the faults and fractures in the area are trending North-South, East-West, and Northeast-Southwest (Fig 2). Most of the geomorphological features and drainage systems are controlled by these fractures and faults.

The geologic formations in the area can be broadly classified into two main aquifers: the unconsolidated sediment aquifer and the volcanic aquifers. The unconsolidated sediments are found along the riverside and at the base of the mountains in the form of alluvial fans in the lowland plain part of the study area. This aquifer is composed of alluvial deposits like boulder, pebble, gravel, and sand. Based on the geological logs of boreholes and geophysical surveying results, the average thickness of this aquifer is about $30 \mathrm{~m}$. There are also localized thin pyroclastic deposits of variable size interbedded with lava flow which help lateral migration of groundwater beneath the unconsolidated sediments which are included in this upper aquifer category. However, these unconsolidated sediments and pyroclastic deposits are of limited hydrogeological importance in the study area due to their limited lateral and vertical extent as compared to the volcanic aquifers.

The volcanic aquifers show both the primary and secondary porosity and permeability. The primary porosity and permeability of the volcanic aquifers include vesicles or gas cavities and porous flow textures. However, weathering and fracturing also play a great role in the groundwater potential of the volcanic aquifers. The volcanic aquifers are characterized by using twelve pumping test data from drilled wells (Fig 2). The yield of the wells mainly penetrating the volcanic aquifers ranges from $41 / \mathrm{sec}$ to $391 / \mathrm{sec}$ (Table 2). The pumping test data analyses were made by using the aquitest-v4 software and the results show that the transmissivity ranges between $4.6 \mathrm{~m}^{2} /$ day - 768 $\mathrm{m}^{2}$ /day (Table 2 and Fig 2). Based on the aquifer classification by Krasny (1993), the transmissivity values of most of the aquifers lay in the moderate to high transmissivity category (Tables $1 \& 2$ and Figs $2 \& 3$ ). In all boreholes, the major water-bearing formations observed are weathered and fractured basalt and vesicular basalt.

Spring discharge of the study area varies from 0.02 to 1.5 1/s. Springs like SP8 (1.2 1/s), SP9 (0.3 1/s), SP11 (1.2 1/s), and SP12 (0.2 1/s) are discharged from Lumame basalt, SP3 (1 1/s) and SP10 $(0.5$ 1/s) from Yejebu basalt and follows the fault line in the area. SP1 $(0.651 / \mathrm{s})$, SP2 $(0.5$ 1/s), SP4 (1.5 1/s), SP6 (0.55 1/s), and SP7 (0.6 1/s) are located in the ignimbrite rocks and SP1 and SP 2 are aligned along the fault.

The partially penetrating boreholes in the sediments and the upper weathered and fractured aquifer and fully penetrating boreholes that penetrated into the volcanic aquifers do not show 
match difference in their depth to groundwater level indicating that the different litho-stratigraphic units can be considered as hydraulically interconnected. Therefore, a single layer, 2-D, steadystate condition, and confined aquifer layer was considered for the modeling practice in this study. The quantification of the groundwater recharge in the study area was made based on precipitation distribution, geologic character, soil type, land use/land cover and topography of the area by using water balance method (De Vries and Simmers, 2002; Lucas et al., 2012; Diniz Melo et al., 2015) and it is estimated to be around $267.02 \mathrm{~mm} /$ annum $\left(7.3 \times 10^{-4} \mathrm{~m} /\right.$ day $)$.

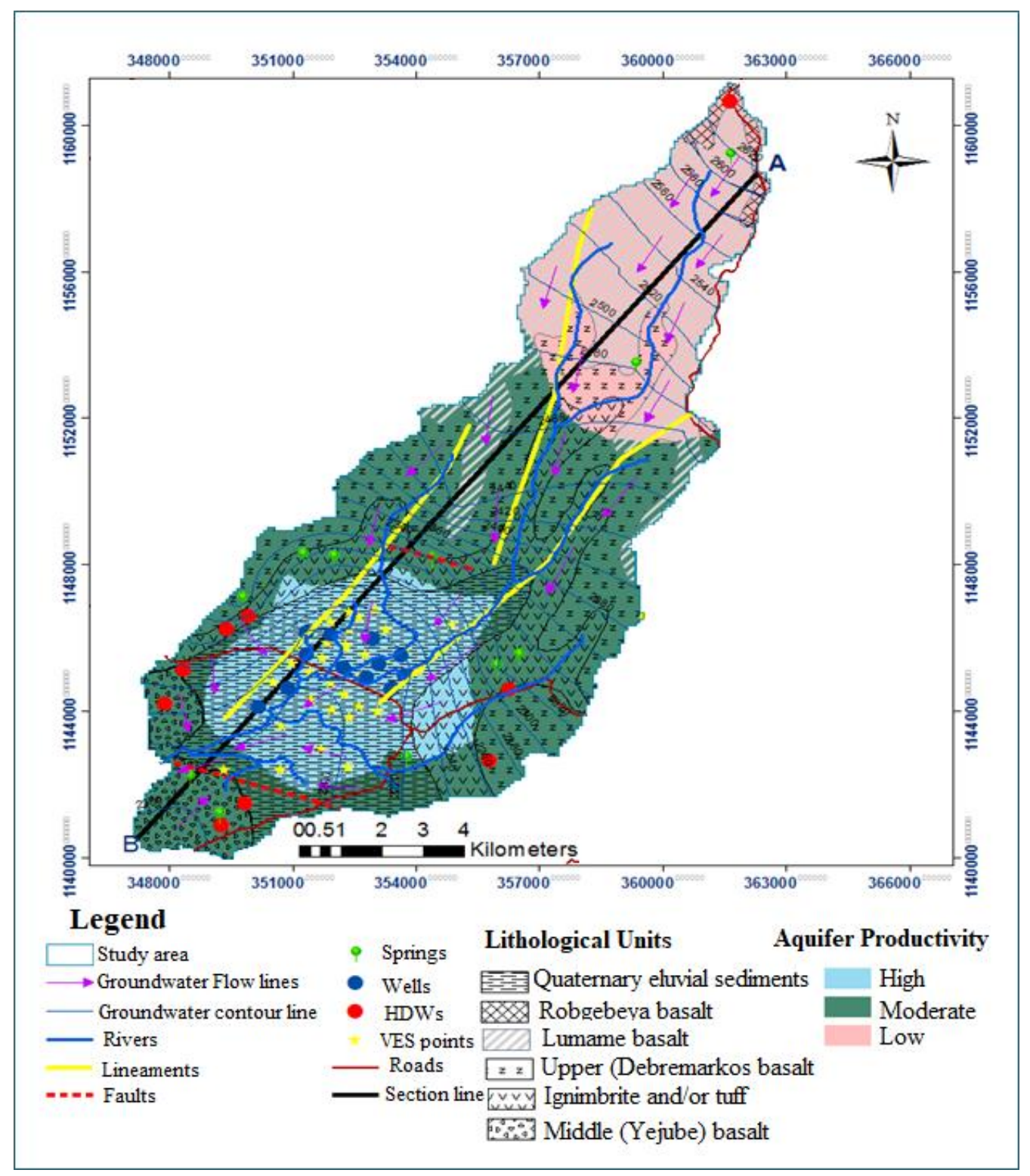

Figure 2. Hydrogeological map of the study area (Geological map is modified from Amhara Design Supervision and Works Enterprise: ADSWE, 2017). 
Table 1. Classification of transmissivity magnitude (Krasny's, 1993).

\begin{tabular}{|l|l|}
\hline $\begin{array}{l}\text { Transmissivty values } \\
\text { in } \boldsymbol{m}^{2} / \text { day }\end{array}$ & $\begin{array}{l}\text { Designation of transmissivty } \\
\text { magnitude }\end{array}$ \\
\hline$<0.1$ & Imperceptible \\
\hline $0.1-1$ & Very Low \\
\hline $1-10$ & Low \\
\hline $10-100$ & Moderate \\
\hline $100-1000$ & High \\
\hline$>1000$ & Very high \\
\hline
\end{tabular}

Table 2. Aquifer properties and productivity of BHs in the study area.

\begin{tabular}{|c|c|c|c|c|c|c|c|c|c|c|}
\hline Well No. & $X$ & $Y$ & $Z$ & $\begin{array}{l}\text { Depth } \\
\text { (m) }\end{array}$ & $\begin{array}{l}S W L \\
(m)\end{array}$ & $Q(l / s)$ & $\begin{array}{l}K \\
(m / d)\end{array}$ & $\begin{array}{l}T \\
\left(m^{2} / d\right)\end{array}$ & $\begin{array}{l}\text { Type of aquifer } \\
\text { (lithology) }\end{array}$ & $\begin{array}{l}\text { Aquifer } \\
\text { productivity } \\
\text { classification } \\
\text { (Krasny 1993) }\end{array}$ \\
\hline DMTW5 & 351344 & 1146171 & 2216 & 152 & 21.1 & 4 & 0.2 & 4.6 & $\begin{array}{l}\text { Slightly to } \\
\text { Moderately } \\
\text { fractured vesicular } \\
\text { basalt }\end{array}$ & Low \\
\hline DMTW9 & 352950 & 1145988 & 2213 & 120 & 18.6 & 7 & 1.58 & 31.7 & $\begin{array}{l}\text { Fractured vascular } \\
\text { basalt }\end{array}$ & \multirow[t]{7}{*}{ Moderate } \\
\hline DMTW8 & 353630 & 1145536 & 2215 & 150 & 15.9 & 15 & 1.36 & 35.3 & $\begin{array}{l}\text { Weathered volcanic } \\
\text { rock (interlayered } \\
\text { basalt and } \\
\text { pyroclastic } \\
\text { material) }\end{array}$ & \\
\hline DMTW12 & 353739 & 1144996 & 2215 & 110 & 12.75 & 15 & 1.3 & 37.7 & $\begin{array}{l}\text { Moderately to } \\
\text { highly fractured } \\
\text { vesicular basalt }\end{array}$ & \\
\hline DMTW6 & 353104 & 1145300 & 2210 & 106 & 16.58 & 27 & 1.54 & 49.2 & $\begin{array}{l}\text { Slightly fractured } \\
\text { vesicular basalt }\end{array}$ & \\
\hline DMTW10 & 352820 & 1144920 & 2206 & 102 & 13.87 & 14 & 2.29 & 82.6 & $\begin{array}{l}\text { Highly fractured } \\
\text { vesicular basalt }\end{array}$ & \\
\hline DMTW11 & 353420 & 1144623 & 2213 & 106 & 19.73 & 39 & 3.16 & 94.9 & $\begin{array}{l}\text { Moderately to } \\
\text { highly fractured } \\
\text { vesicular basalt }\end{array}$ & \\
\hline DMTW7 & 350905 & 1144642 & 2200 & 184 & 9.93 & 30 & 4.79 & 95.9 & $\begin{array}{l}\text { Vesicular basalt } \\
\text { and weathered } \\
\text { volcanic rock } \\
\text { (pyroclastic) }\end{array}$ & \\
\hline DMTW4 & 351929 & 1146087 & 2214 & 150 & 18.2 & 21 & 3.6 & 143 & $\begin{array}{l}\text { Moderately to } \\
\text { highly fractured } \\
\text { vesicular basalt }\end{array}$ & \multirow[t]{4}{*}{ High } \\
\hline DMTW3 & 351349 & 1145548 & 2210 & 149 & 10.75 & 23.4 & 6.11 & 159 & $\begin{array}{l}\text { Highly fractured } \\
\text { vesicular basalt }\end{array}$ & \\
\hline DMTW2 & 352229 & 1145203 & 2208 & 102 & 12.75 & 5 & 19.8 & 593 & $\begin{array}{l}\text { Highly fractured } \\
\text { and slightly } \\
\text { weathered vesicular } \\
\text { basalt }\end{array}$ & \\
\hline DMTW1 & 353413 & 1144609 & 2213 & 84 & 12.5 & 22.24 & 25.6 & 768 & $\begin{array}{l}\text { Highly fractured } \\
\text { vesicular basalt }\end{array}$ & \\
\hline
\end{tabular}




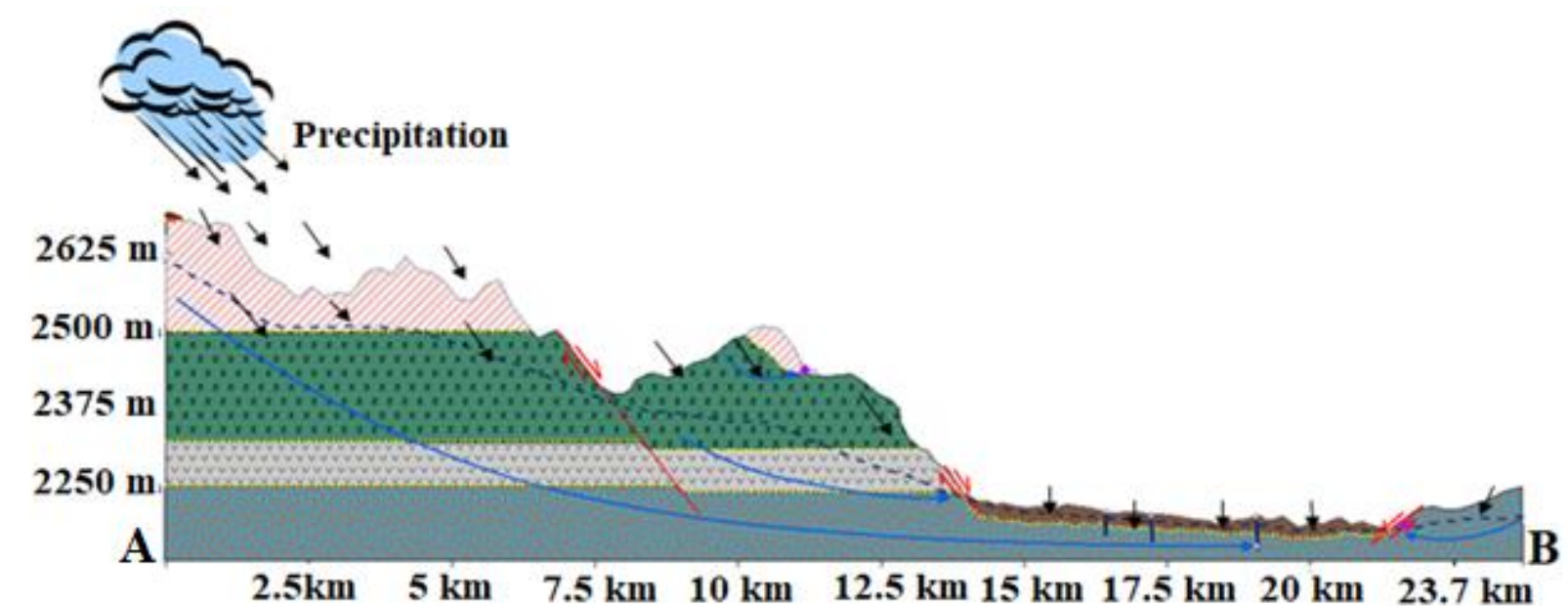

Figure 3. Hydrogeological cross sections (Line of section indicated in Fig. 2).

\section{METHODOLGY}

In this research, the appropriate computer code/MODFLOW-2000 (McDoland and Harbaugh, 1988 as developed by USGS) was used to simulate the numerical groundwater flow system in the study area using Processing MODFLOW program. The MODFLOW is widely used, tested, and verified software. It is a water balance computation incorporated model that simulates all hydrologic features independently using its grouped packages. It is a deterministic model approach that assumes the stage or response of aquifer is predetermined by the help of physical laws governing the groundwater flow.

The Arc GIS 10.1 was also used to develop the location map and the geological and hydrogeological maps of the study area. Landsat images were used to delineate the study area boundary and conceptualize the boundary conditions. The surface water divide of the study area is assigned as a no-flow boundary, recharge, and well discharge are represented using specifiedflux boundaries, and rivers are represented as head-dependent flux boundaries. Recharge to the groundwater systems was estimated using the water balance method (De Vries and Simmers, 2002; Lucas et al., 2012; Diniz Melo et al., 2015). Assumptions are made to derive the water balance equation of the study area surface water divide coincides with groundwater divided hence the groundwater in the basin is in closed system, the change in the storage on annual basis is assumed to be zero surface and subsurface water exchange with neighboring catchment is assumed to be zero, assuming no artificial diversion from other catchments, since the computation is made on 
annual basis, a net change of the soil moisture and groundwater storage is assumed to be zero. Aquifer properties were determined using Aquitest-4 software from the pumping test data.

The volume of water that leaves as surface runoff from Dijil river catchment is $396.11 \mathrm{~mm} /$ year calculated by the Rational Method (Chow et al., 1988). A rational approach is to obtain the yield of a catchment by assuming a suitable runoff coefficient. (Eq. 1). The value of the runoff coefficient $\mathrm{C}$ varies depending upon the soil type, vegetation, and slope.

Surface Run off $=$ CAP Equation 1

Where, $\mathrm{A}=$ area of catchment, $\mathrm{P}=$ precipitation, $\mathrm{C}=$ runoff coefficient.

Calibration of the model was done using the field measured heads, by adjusting parameters based on trial and error method. The Mean Error (ME), Mean Absolute Error (MAE) and Root Mean Squared Error (RMSE) Error were computed to express the average difference between simulated and measured heads are commonly used (Duffield et al., 1990; Ghassemi et al., 1989; Konikow and Bredehoefet, 1978; Anderson and Woessner, 1992).

ME is the mean difference between the measured heads $\left(\mathrm{h}_{\mathrm{m}}\right)$ and simulated heads $\left(\mathrm{h}_{\mathrm{s}}\right)$.

$M E=\frac{1}{n} \sum_{i=1}^{n}\left(h_{m}-h_{s}\right) i$ Equation 2

Where, $\mathrm{n}$ - is the number of calibration value at a given target (i).

MAE is the mean absolute value of the difference in measured and simulated heads.

$M A E=\frac{1}{n} \sum_{i=1}^{n}\left|h_{m}-h_{s}\right|_{i}$ Equation 3

RMS Error or the standard deviation is the average of squared differences in measured and simulated heads.

$$
R M S E=\sqrt{\frac{1}{n} \sum_{i=1}^{n}\left|h_{m}-h_{s}\right|_{i}}
$$

Equation 4

\section{RESULTS AND DISCUSSION}

\subsection{Numerical Model}

\subsubsection{Simulation Code}

The numerical groundwater flow modeling of the Dijil river catchment, the general 3-D governing equation has been adjusted according to the prevailing field condition (Eq. 5). During the conceptual model development, it is identified that there is no significant variation in water level and recharge in the catchment. Therefore, the conceptualized model is a steady-state, two 
dimensional confined aquifer and a single layer with no possible flow in the $\mathrm{Z}$ direction; the equation can be simplified and rewritten into the following equation (Eq. 6).

$\frac{\partial}{\partial x}\left(K_{X X} \frac{\partial}{\partial x}\right)+\frac{\partial}{\partial y}\left(K_{y y} \frac{\partial}{\partial y}\right)+\frac{\partial}{\partial z}\left(K_{z z} \frac{\partial}{\partial z}\right)-W=S_{s} \frac{\partial h}{\partial t}$ Equation 5

Where,

$\mathrm{K}_{\mathrm{xx}}, \mathrm{K}_{\mathrm{yy}}$ and $\mathrm{K}_{\mathrm{zz}}$ are the values of hydraulic conductivity along the $\mathrm{x}, \mathrm{y}$ and $\mathrm{z}$ coordinate axes (L/T). $\mathrm{h}$ is the hydraulic head $(\mathrm{L})$.

$\mathrm{W}$ is a volumetric flux per unit volume representing sources and/or sinks of water, where negative values are extractions, and positive values are injections $\left(\mathrm{LT}^{-1}\right)$.

$\mathrm{S}_{\mathrm{s}}$ is the specific storage of the aquifer material $\left(\mathrm{L}^{-1}\right)$; and $\mathrm{t}$ is time $(\mathrm{T})$

Steady state is characterized with no storage or change of head through the hydrological year.

$\left.\frac{\partial}{\partial x}\left(K_{X X} \frac{\partial}{\partial x}\right)+\frac{\partial}{\partial y} K_{y y} \frac{\partial}{\partial y}\right)-W=0$

Equation 6

Where,

$\mathrm{W}$ is a general sink or source basically positive to represent recharge and negative for withdrawal of groundwater from aquifer system.

\subsubsection{Spatial Discretization and Grid Layout}

A grid with a small number of nodes is preferred to minimize data handling, computer storage and computation time (McDoland and Harbaugh, 1988; Anderson and Woessner, 2002; Kresic, 2007; Anderson et al., 2015). Two sets of parallel lines form a grid and are orthogonal. These lines form blocks which are called cells and the node is the point at which the model measures hydraulics. Hydraulic and hydrogeological properties are presumed to be consistent over a cell's length so that its node represents the cell (Batu, 2006; Anderson et al., 2015).

In this work, the model discrete with a uniform cell size of $100 \mathrm{~m}$ by $100 \mathrm{~m}$ with 211 row and 154 column arrays in a single layer. The model uses a total number of 32,494 cells in which only 13,828 are active and used to compute the hydraulic head and the remaining number of cells are inactive cells (Fig 4).

\subsubsection{Boundary Conditions}

Boundary conditions are mathematical statements specifying the dependent variable (head) or the derivative of the dependent variable (flux) at the boundaries of the problem domain (Anderson and Woessner, 1992).

The model under study considers the volcanic ridge surface water divide as the no-flow boundary and the same time the decreasing of the conductivity down the depth of the aquifer as 
bottom no-flow boundary. The model also considers specified head boundary which is simulated by setting the head at the relevant boundary nodes equal to known values. The southeastern and southwestern part of the study area is considered as a specific head boundary. Three types of boundary conditions were used to define the groundwater flow system in Dijil river catchment: no-flow boundaries, specified-flux boundaries, and head-dependent flux boundaries (McDoland and Harbaugh, 1988; Anderson and Woessner, 2002; Kresic, 2007; Anderson et al., 2015). Geologic or hydrologic barriers to groundwater flow were simulated using no-flow boundaries. In the study area, the contact between the permeable groundwater flow system and nearly impermeable bedrock is an example of a no-flow boundary. Known or estimated hydrologic fluxes, such as recharge and well discharge, are represented using specified-flux boundaries (Fig 4).

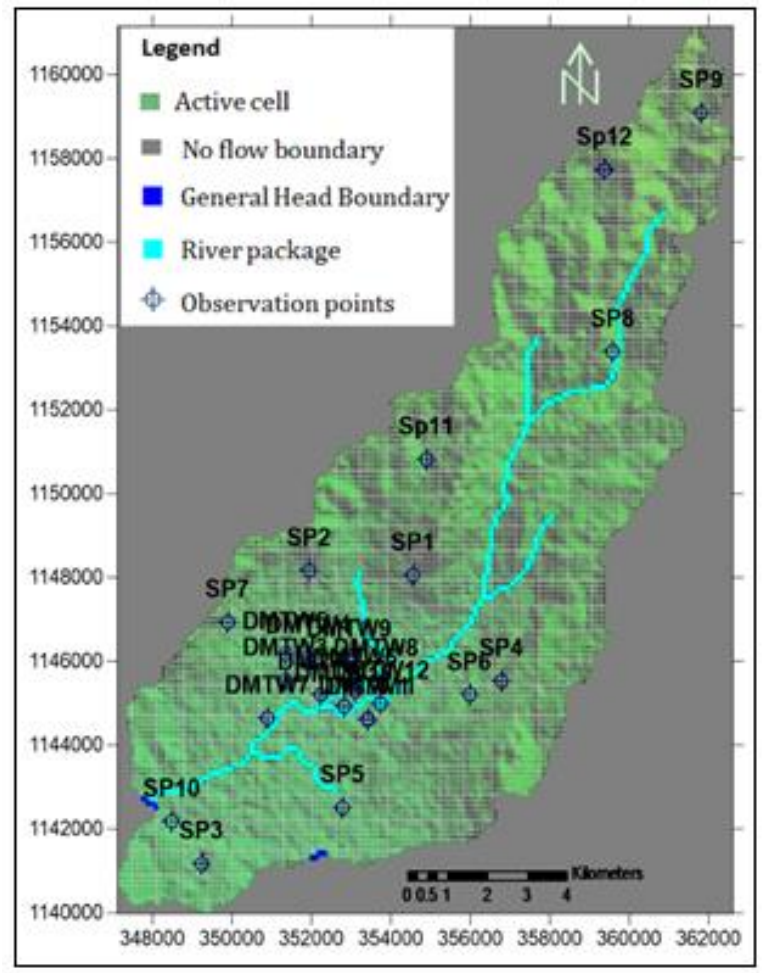

Figure 4. Boundary condition of the study area.

\subsubsection{Model Calibration}

There are two ways of finding model parameters to achieve calibration; manual trial and error adjustment of parameters and automated parameter estimations (Kresic, 1997; Wang and Anderson, 1982, Anderson and Woesser, 1992). In this model, calibration was performed by the traditional trial and error processes in which model parameters and hydrologic stresses were 
adjusted manually within reasonable limits of existing data and field hydrogeological observation to achieve the best model fit. Additionally, hydrologic stresses literature review and point hydraulic conductivity and transmissivity data were used as initial guessing during calibration of hydraulic conductivity. The calibration criteria set by the modeler is to match simulated groundwater head and hydraulic gradient with an estimated one by taking into account the variation of horizontal hydraulic conductivity of aquifers in a small distance. Water level measurement data (primary and secondary data) of 24 water points have been used to calibrate the model.

The qualitative methods of calibration evaluation that are applied in this study are the comparison of the observed and simulated head contour, post errors in the contour and the scatterplot. A comparison between contour maps of measured and simulated heads (Fig 5) provides a visual, qualitative measure of the similarity between patterns, thereby giving some idea of the spatial distribution of error in the calibration.

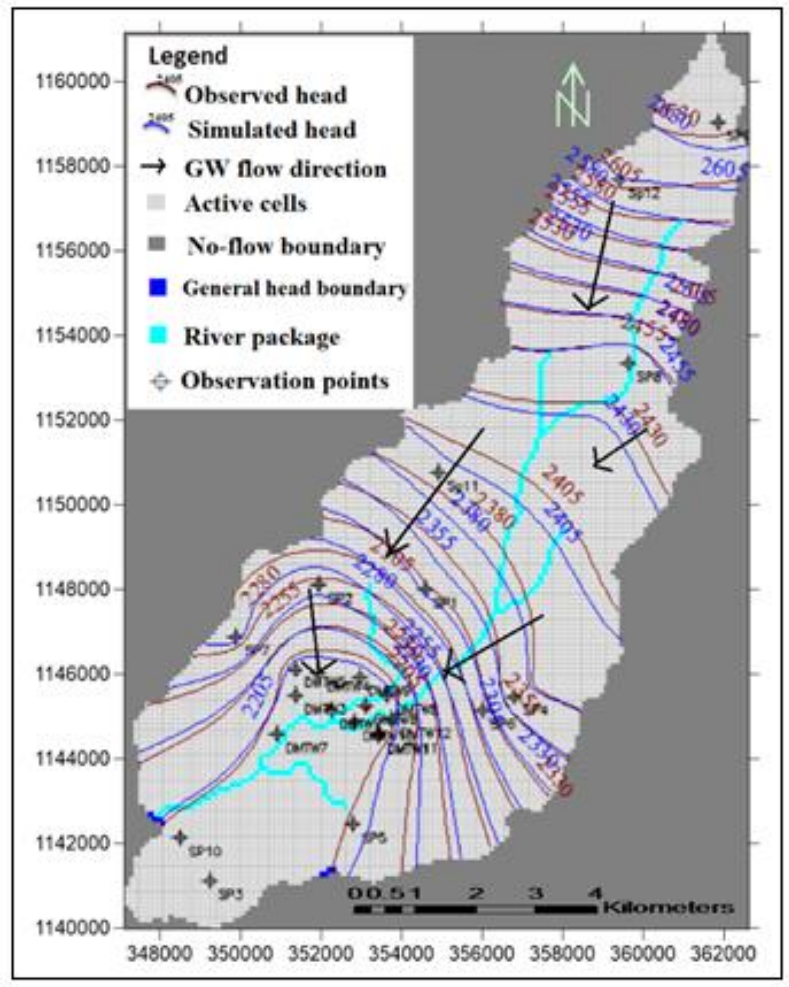

Figure 5. Observed Vs Simulated head contours and groundwater flow direction of the study area.

The other is a listing of measured and simulated heads together with their differences and some type of average of the differences is a common way of reporting calibration results, this 
includes mean error (ME), Mean absolute Error (MAE) and Root Mean Square Error (RMS). The difference is called error or residual. It is computed by subtracting the model computed value (head, drawdown) from the target value. The negative residual indicates that the model is calculating the dependent value too high and the positive residual is where the model value is too low.

The tolerable ranges of MA, MAE, and RMSE should be predetermined and comprised of the conceptual model based on information concerning measurement errors and aquifer test conditions. Frequently, MA, MAE, and RMSE values within $\pm 5 \%$ of measured head values are considered acceptable. Calibration is sometimes deemed acceptable when calculated head values are within two standard deviations of calculated time-drawdown or time-head values (William, 2007). In the present study, the resulting model has a mean error of $-2.1 \mathrm{~m}$ that is not too far to be a good calibrated model, an absolute residual mean of $6.43 \mathrm{~m}$ which is below the residual criteria set before the calibration process and has resulted $7.31 \mathrm{~m}$ root mean squared error of standard deviation which is a good range in calibrations. For an ideal calibration, the scatter plots where observed values are plotted against the value computed by the model, the points will fall on the straight line with a 45 degree slope that means the computed value equals the measured value. The correlation between observed and simulated values is significant and the determination coefficient is high: $\mathrm{R}^{2}=0.99$ (Fig 6).

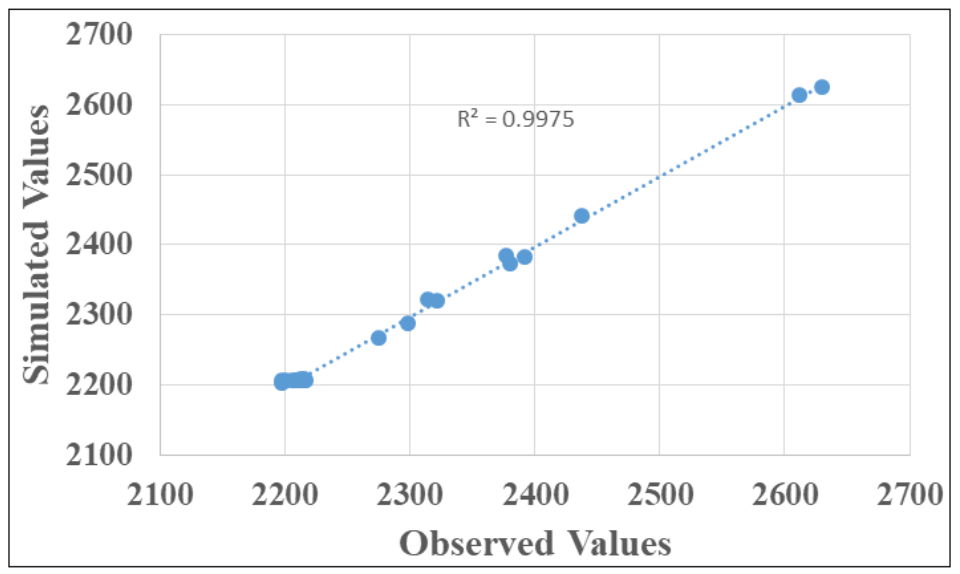

Figure 6. Comparison of the model computed and observed hydraulic head data after model calibration.

\subsubsection{Sensitivity Analysis}

The purpose of sensitivity analysis is to quantify the uncertainty in the calibrated model caused by uncertainty in the estimated values of the aquifer parameters, stresses, and boundary conditions 
(Anderson and Weossner, 1992). It is the process of varying model input parameters over a reasonable range (range of uncertainty in values of model parameters) and observing the relative change in model response. The determination of a sensitivity analysis is to quantify the uncertainty in a calibrated model caused by uncertainty in the estimates of aquifer parameters, stresses and boundary conditions of the model area (Senthil and Elango, 2004).

In this study, following the calibration, the sensitivity analysis was carried out by changing (increasing and decreasing by $25 \%, 50 \%$, and $75 \%$ ) the calibrated model parameters such as hydraulic conductivity, recharge and river bed conductance (Fig 7).

Generally, the model is found to be more sensitive for decreasing of the three parameters (hydraulic conductivity, recharge and river bed conductance) than increment. And hydraulic conductivity is found as the most sensitive parameter (Fig 7).

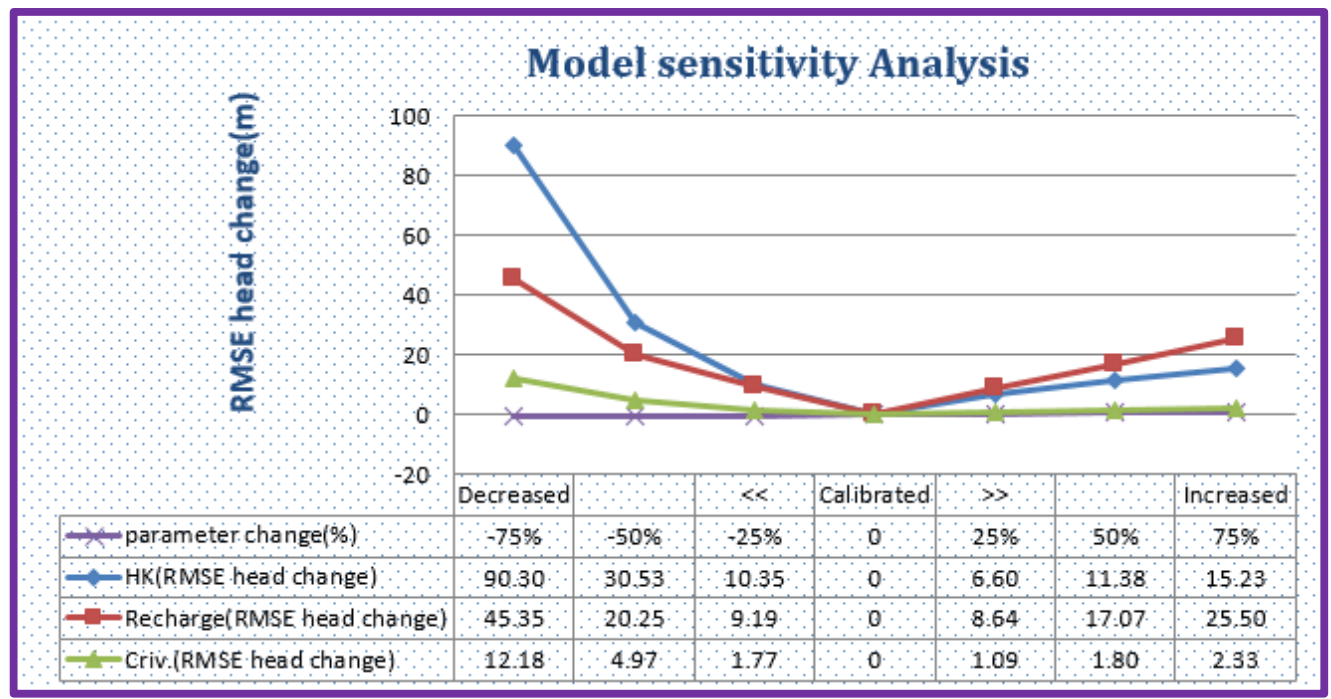

Figure 7. Model Sensitivity.

\subsubsection{Simulated Water Balance Result}

The simulated water budget has been computed for the study area (Table 3). The simulated inflow of the model is $1.2791870 \mathrm{E}+05 \mathrm{~m}^{3} /$ day which is nearly equal to simulated outflow $1.2791755 \mathrm{E}+05$ $\mathrm{m}^{3} /$ day with a difference of $1.1484375 \mathrm{E}+00 \mathrm{~m}^{3} /$ day. Recharges from precipitation, river leakage, and groundwater enters the aquifer across the southeastern general head boundary are the major inflow components. River leakage simulated discharge holds $92.8 \%$ of the outflow. It also contributed as recharge into the aquifer that accounts for $14.1 \%$ of the inflow. Hence in this 
catchment, it can be generalized that the contribution of the groundwater to the rivers is higher than the contribution of the river to the groundwater (Fig 5).

Groundwater leaving the aquifer, across the southwestern general head boundary and abstraction by pumping for the domestic, industrial and agricultural purpose also contribute some proportions to the outflow from the Dijil river catchment. Groundwater leaving the aquifer across the general head boundary holds $4.3 \%$ of the total outflow and that enters to the aquifer accounts to $3.3 \%$ of the total inflow (Table 3). Detail water budget result is finding in the table 3 .

Table 3. Water budget analysis of the study area.

\begin{tabular}{|llll|}
\hline Flow Terms & Inflow & Outflow & Inflow-Outflow \\
\hline Wells & $0.0000000 \mathrm{E}+00$ & $3.6720000 \mathrm{E}+03$ & $-3.6720000 \mathrm{E}+03$ \\
\hline Recharge & $1.0562849 \mathrm{E}+05$ & $0.0000000 \mathrm{E}+00$ & $1.0562849 \mathrm{E}+05$ \\
\hline River Leakage & $1.8069048 \mathrm{E}+04$ & $1.1868844 \mathrm{E}+05$ & $-1.0061939 \mathrm{E}+05$ \\
\hline Head Dep. bounds & $4.2211542 \mathrm{E}+03$ & $5.5571083 \mathrm{E}+03$ & $-1.3359541 \mathrm{E}+03$ \\
\hline Sum & $1.2791870 \mathrm{E}+05$ & $1.2791755 \mathrm{E}+05$ & $1.1484375 \mathrm{E}+00$ \\
\hline DISCREPANCY [\%] & 0.00 & & \\
\hline
\end{tabular}

\subsubsection{Scenario Analysis}

A calibrated flow model can be used as a tool to evaluate and compare the responses of an aquifer system to potential future stresses. In this study, the model was used to simulate the aquifer-system response to increased withdrawals and decreased recharge.

In all scenarios, other model parameters were kept to the steady-state values except the stress for which the projection was carried out and the resulting changes in water levels and fluxes are interpreted as responses of the system to the changes introduced on it.

In the study area, industrialization and urbanization is booming. Thus, it is logical to think that groundwater withdrawal will increase in the catchment and it is necessary to project its future effects on groundwater table and fluxes of the area so that appropriate water management practices that could mitigate the likely adverse effects of increased withdrawal can be proposed. To evaluate this condition, three scenarios were made: First, simultaneous pumping of the existing wells for 12 hours/day, second scenario is made by increasing the existing withdrawal $\left(3672 \mathrm{~m}^{3} / \mathrm{day}\right)$ by $30 \%$ and the third scenario is made by drilling eight additional new wells with $30 \mathrm{l} / \mathrm{s}$ yield from each additional well (Table 4). 
As it has been seen in the scenario analysis result, the increasing of well withdrawal has adverse effect on stream leakage and groundwater outflow but relatively less impact on groundwater head. System responses to increased groundwater withdrawal for the above scenarios are shown in table 4 and figure 7. The different scenario results shows that the change in drawdown, river leakage and sub-surface outflow in the third scenario is about four times than the first scenario. Therefore, the managed aquifer recharge (MAR) technologies can provide a variety of water resources management benefits by increasing the volume of stored water and decreasing the drawdown in the aquifer.

Table 4. System response to increased groundwater withdrawal.

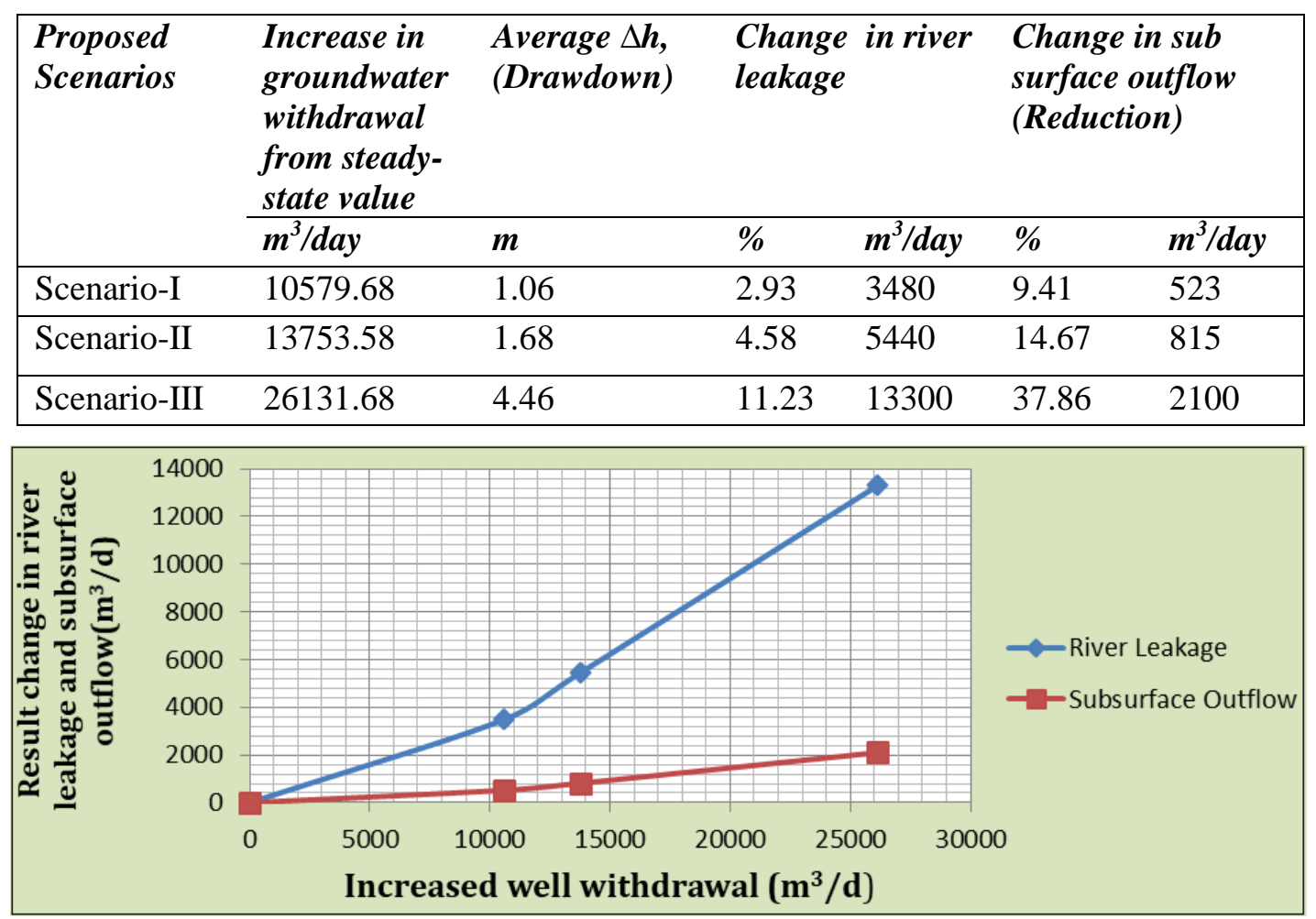

Figure 7. Trend of system response to increased groundwater withdrawal rates for river leakage and subsurface outflow.

The second scenario has been done by decreasing recharge to aquifers that may result from the expansion of agriculture, deforestation, urbanization, and decreasing precipitation. If the recharge is decreased by $25 \%$ and $50 \%$, the simulation results showed on an average head decrease of $6.1 \mathrm{~m}$ and $13.4 \mathrm{~m}$ over the whole area. Moreover, a stream leakage decrease as compared to the 
simulated steady-state value, and the changes was about $20.3 \%$ and $40.3 \%$. This indicates decreasing recharge has an adverse effect on the groundwater table and stream leakage.

\section{CONCLUSION}

The calibrated steady-state groundwater flow model of this study was able to reasonably simulate the hydraulic heads that fit the measured heads particularly for the lowland plain part of the catchment. Besides, the model simulated heads contour map shows that the general hydraulic gradient in the basin pursues the surface topography and the gradient is towards the north-south direction and it was in agreement with the groundwater flow system defined in the conceptual model. A minor local irregularity of flow pattern is attributed to the existence of geologic structures.

As the model was intended to study the response of the hydrologic system, three scenarios of increased withdrawals and one scenario of altered recharge were used to study the system response. The effects of the scenarios were evaluated with respect to changes induced on stream leakage, subsurface outflow and groundwater heads compared to the steady-state simulated values.

Accordingly, an increase in well withdrawal of scenario-I (existing wells pump simultaneously), scenario-II (existing drilled wells yield withdrawal increased by 30\%) and Scenario-III (additional eight wells having expected yield of $30 \mathrm{l} / \mathrm{s}$ drill and pump) resulted in an average decline of the steady state water level by $1.06 \mathrm{~m}, 1.68 \mathrm{~m}$ and $4.46 \mathrm{~m}$, respectively and caused the steady state stream leakage to be reduced by about $2.93 \%, 4.58 \%$ and $11.23 \%$, and subsurface outflow by $9.41 \%, 14.67 \%$ and $37.86 \%$, respectively over the whole catchment. A second scenario was done by decreasing the recharge values shows that a decrease head and a stream leakage in the whole area of study.

An adequate groundwater level monitoring wells should be placed in the catchment to control the total abstraction rates from the aquifer and fluctuations in groundwater levels.

\section{ACKNOWLEDGEMENTS}

The first author wish to thank to Amhara Design and Supervision Works Enterprise, Bahirdar branch for financial support. We are also grateful to the two anonymous reviewers, whose suggestions significantly improved the quality of the paper. 


\section{CONFLICT OF INTEREST}

No conflict of interest.

\section{REFERENCE}

ADSWE, 2017. Geological, Geomorphological and Structural Study of North and South Gojam of Abay Basin for Groundwater Potential Assessment. Report, Bahir Bar, Ethiopia (unpubl.).

Anderson, M.P \& Woessner, W.W. 1992. Applied Groundwater Modeling, Simulation of Flow and Advective Transport. Academic press. Florida, 381p.

Anderson, M. P \& Woessner, W.W. 2002. Applied groundwater modeling - Simulation of flow and advective transport. Academic Press. United Kingdom, 630p.

Anderson, M.P., Woessner, W.W \& Hunt, R.J. 2015. Applied Groundwater Modeling: Simulation of Flow and Advective Transport. $2^{\text {nd }}$ Edition, Academic Press, Inc. 564p.

Ayalew, A., Hailemariam, D., Fekadu Hailu, F., Chumburo, F., Mulugeta Hailemariam, M \& Alemayehu, T. 2015. Geology of Debremarkos Map Sheet (NC 37-6). Memoir No. 27. Federal Democratic Republic of Ethiopia, Ministy of Mines, Geological Survey of Ethiopia, Basic Geoscience Mapping Core Process, Addis Ababa, Ethiopia.

Batu, V. 2006. Applied Flow and Solute Transport Modeling in Aquifers: Fundamental Principles and Analytical and Numerical Methods. CRC press. New York, 696p.

Bresciani, E., Gleeson, T., Goderniaux, P., de Dreuzy, J.R., Werner, A.D., Wörman, A., Zijl, W \& Batelaan, O. 2016. Groundwater flow systems theory: research challenges beyond the specified-head top boundary condition. Hydrogeology Journal, 24: 1087-1090 (https://doi.org/10.1007/s10040-016-1397-8).

Cardenas, M.B \& Jiang, X.W. 2010. Groundwater flow, transport, and residence times through topography-driven basins with exponentially decreasing permeability and porosity. Water Resour Research, 46:W11538 (https://doi.org/10.1029/2010WR009370).

Chow, V.T., Maidment, D.R \& Mays, L.W. 1988. Applied Hydrology. International Edition, McGraw-Hill Book Company, New York.

Debre Markos town water and sewerage office 2016. Existing wells inventory data report of North and South Gojam Abay basin groundwater potential assessment project. Report (unpubl.). 
Debre Markos town water and sewerage office 2017. Well rehabilitation (Sentera well field). Report (unpubl.).

De Vries, J \& Simmers, I. 2002. Groundwater recharge: an overview of processes and challenges. Hydrogeology Journal, 10: 5-17.

Diniz Melo, D.C., Edson Wendland, E \& Guanabara, R.C. 2015. Estimate of Groundwater Recharge Based on Water Balance in the Unsaturated Soil Zone. Revista Brasileira de Ciência do Solo, 39: 1335-1343.

Duffield, G.M., Buss, D.R \& Stephenson, D.E. 1990. Velocity prediction errors related to flow model calibration uncertainty. In: Calibration and Reliability of Groundwater Modelling, K. Kovar (Ed.), Publication 195, International Association of Hydrogeologic Sciences, Wallingford, pp. 397-406.

Getachew, H. 2008. Groundwater Contribution and Recharge Estimation in the Upper Blue Nile Flows, Ethiopia. MScs Thesis (Unpublished). International Institute for Geo-Information Science and Earth Observation Enscheda, The Netherlands.

Getaneh, A. 1991. Lithostratigraphy and environment of deposition of the Late Jurassic-Early Cretaceous sequence of the central part of Northwestern Plateau, Ethiopia. N. Jb. Geol. Paläont. Abh., 182(3): 255-284.

Ghassemi, F.A., Jakeman, A.J \& Thomas, G.A. 1989. Groundwater modeling for salinity management: an Australian case study. Ground Water, 27(3): 384-392.

Havril, T., Toth, A., Molson, J.W., Galsa, A.W \& Mádl-Szonyi, J. 2017. Impacts of predicted climate change on groundwater flow systems: can wetlands disappear due to recharge reduction? Journal of Hydrology, 563:1169-1180.

Huizar-Alvarez, R., Ouysse, S., Espinoza-Jaramillo, M.M., Carrillo Rivera, J.J \& MendozaArchundia, E. 2016. The effects of water use on Tothian flow systems in the Mexico City conurbation determined from the geochemical and isotopic characteristics of groundwater. Environ Earth Science, 75(1060), (https://doi.org/10.1007/s1266 5-016-5843-7).

Konikow, L.F \& Bredehoft, J.D. 1978. Computer Model of Two Dimensional Solute Transport and Dispersion in Groundwater. Techniques of Water Resources Investigation. Book 7, Chapter 2, U.S. Geological Survey, Reston, Virginia.

Krasny, J. 1993. Classification of Transmissivity Magnitude and Variation. Groundwater, 31(2): 230-236. 
Kresic, N. 1997. Hydrogeology and Groundwater Modeling. CRC Press LLC, USA, 480p.

Kresic, N. 2007. Hydrogeology and Groundwater Modeling. CRC Press LLC, USA, 807p.

Lucas, M.C., Guanabara, R.C \& Wendland, E. 2012. Estimating groundwater recharge in the outcrop area of the Guarani Aquifer System. Bulletin of Geological and Mining, 123: 311323.

McDonald, M. G \& Harbaugh, A. W. 1988. A modular three-dimensional finite-difference groundwater flow model. Techniques of Water-Resources Investigations, 06-A1, USGS, $576 \mathrm{p}$.

Mussa, K.R., Mjemah, I, C \& Muzuka, A.N.N. 2020. A review on the state of knowledge, conceptual and theoretical contentions of major theories and principles governing $\begin{array}{lllll}\text { groundwater flow modeling. Applied Water } & \text { Science, }\end{array}$ (https://doi.org/10.1007/s13201-020-01202-6).

Pinder, G. F \& Gray, W.G. 1977. Finite element simulation in surface and subsurface hydrology, Academic Press, New York, 308p.

Prickett, T.A \& Lonnquist, C.G. 1971. Selected Digital Computer Techniques for Groundwater Resource Evaluation. State Water Survey Division, 55: 8-61.

Samson, M. 2010. Numerical groundwater flow modeling of the Lake Tana basin, upper Nile, Ethiopia. MSc. thesis, Department of Earth Sciences, Addis Ababa University (unpubl.).

Seifu, K. 2004. Environmental isotopes and geochemistry in investigating groundwater and lake hydrology: case from the Blue Nile basin and the Ethiopian Rift (Ethiopia). PhD thesis (Unpublished), University of Avignon, France.

Seifu, K., Travi, Y., Tamiru, A \& Tenalem, A. 2005. Groundwater recharge, circulation and geochemical evolution in the source of the Blue Nile River, Ethiopia. Applied Geochemistry, 20: 1658-1676.

Seifu, K., Girum, A \& Travi, Y. 2012. Estimating un-gauged catchments flows from Lake Tana flood plains, Ethiopia: isotope hydrological approach. Isotopes in Environmental and Health Studies, 47(1): 71-86.

Senthil, K.M \& Elango, L. 2004. Three dimensional mathematical model to simulate groundwater flow in the lower Palar River basin, southern India; J. Hydrogeology, 12(3): 197-208.

SMEC. 2007. Hydrological study of the Tana- Beles sub basins, groundwater investigation. Ministry of Water Resources and Energy. 
Tenalem, A \& Tamiru, A. 2001. Principles of Hydrogeology. Department of Geology and Geophysics, Addis Ababa University, 125p.

Tenbus, F.J \& Fleck, W.B. 1996. Simulation of Ground-Water Flow and Transport of Chlorinated Hydrocarbons at Graces Quarters, Aberdeen Proving Ground, Maryland. USGS Water Resources Investigations Report, 01-4106.

Trescott, P.C., Pinder, G.F \& Larson, S.P. 1976. Finite difference model for aquifer simulation in two dimensions with results of numerical experiments. Techniques of Water-Resources Investigations, 07-C1.

Veiko, K., Ingo V \& Margit, K. 2013. Mine Water as a Potential Source of Energy from Underground Mined Areas in Estonian Oil Shale Deposit. Oil Shale, 30(2): 336-362.

WWDSE, 2007. Groundwater resources in Lake Tana sub-basin and adjacent areas, rapid assessment. Ministry of Water, Irrigation and Energy, Ethiopia (Unpublished Report).

Wang, H. F \& Anderson, M. P. 1982 Groundwater modelling with finite difference and finite element methods. Elsevier Publishing, Amsterdam, 137p.

Wang, S., Shao, J., Song, X., Zhang,Y., Huo, Z \& Zhou, X. 2008. Application of MODFLOW and geographic information system to groundwater flow simulation in North China Plain, China. Environmental Geology, 55:1449-1462.

William C. W. 2007. Aquifer Test Modeling. CRC Press, New York, 238pp

Wolela, A. M. 2002. Hydrocarbon Potential of the Blue Nile Basin, Central Ethiopia. Draft report, Ministry of Mines, Petroleum Operations Department, Addis Ababa.

Zhou, Y \& Li, W. 2011. A review of regional groundwater flow modeling. Geoscience Front, 2(2): 205-214 (https://doi.org/10.1016/j. gsf.2011.03.003). 